\title{
THE EFFECT OF THE WELDING PARAMETERS AND THE COUPLING AGENT ON THE WELDING OF COMPOSITES
}

\author{
VPLIV PARAMETROV VARJENJA IN SREDSTVA ZA SPAJANJE \\ NA VARJENJE KOMPOZITOV
}

\author{
Selcuk Ertugrul Erdogan, Umit Huner \\ Trakya University, Faculty of Engineering, Department of Mechanical Engineering, 22050 Edirne, Turkey \\ umithuner@trakya.edu.tr \\ Prejem rokopisa - received: 2015-03-11; sprejem za objavo - accepted for publication: 2015-09-14
}

doi:10.17222/mit.2015.059

\begin{abstract}
This paper presents an experimental investigation of the welding of a glass-fiber-reinforced PP composite. The goals of this paper are to investigate the issues of local changes of the welding strength that depend on the heating time and the coupling agent (MAPP). Composite samples were prepared by using an extruding (for mixing) process and a hot-press method. The PP matrix was reinforced by unidirectional short glass fibers. The welding process for the specimens was carried out using a non-contact heated tool butt welding process. Tensile and fatigue tests were conducted to investigate the effects of the heating time parameter and the coupling agent. The highest weld strength dependent on the heating time was achieved with $94 \%$ relative to the base strength of the material. The fatigue behavior of short-fiber-reinforced thermoplastic composites (polypropylene/20\% of volume fractions of E-glass fiber) is presented in terms of stress versus the number of cycles to failure. The specimens were fatigue tested at various percentages of their static tensile strengths at a load ratio $R=0.1$ and frequency $f=$ $5 \mathrm{~Hz}$. An indefinite fatigue life was obtained at $35 \%$ of the static damage initiation load for glass-fiber-reinforced specimens. Then, these specimen's maximum welding strengths and fatigue properties that were dependent on the heating time were compared.
\end{abstract}

Keywords: plastic material, composite, heated tool, welding process, reinforcement, fatigue, polypropylene

Članek predstavlja preiskavo varjenja PP kompozita, ojačanega s steklenimi vlakni. Cilj članka je bil preiskati vpliv lokalnih sprememb na trdnost zvara, ki je odvisna od časa ogrevanja in sredstva za spajanje (MAPP). Kompozitni vzorci so bili pripravljeni z uporabo metode ekstruzije in vročega stiskanja. PP osnova je bila ojačana z usmerjenimi kratkimi steklenimi vlakni. Postopek čelnega varjenja vzorcev je bil izveden z brezkontaktno ogrevanim orodjem. Izvedeni so bili natezni preizkusi in preizkusi utrujenosti, da bi ugotovili vpliv časa ogrevanja in sredstva za spajanje. Največja trdnost zvara v odvisnosti od časa ogrevanja je bila $94 \%$ trdnosti osnovnega materiala. Obnašanje pri utrujanju termoplastičnega kompozita (polipropilen/20 \% prostorninskih deležev E-steklenih vlaken), ojačanega s kratkimi vlakni, je prikazano na krivulji utrujanja kot odvisnost napetosti od števila ciklov. Utrujenost vzorcev je bila preizkušana pri različnih odstotkih statične natezne trdnosti, pri hitrosti obremenjevanja $R=0,1$ in frekvenci $f=5 \mathrm{~Hz}$. Zdržljivost na utrujanje s steklenimi vlakni ojačanih vzorcev je bila dobljena pri $35 \%$ nazivne statične obremenitve. Primerjane so bile maksimalne trdnosti zvarov, $\mathrm{z}$ obnašanjem pri utrujanju v odvisnosti od časa ogrevanja.

Ključne besede: plastični material, kompozit, ogrevano orodje, postopek varjenja, ojačanje, utrujenost, polipropilen

\section{INTRODUCTION}

In high-technology applications, a composite is suitably qualified due to the fact that it has a higher strength and a better stiffness-to-weight ratio. The vital properties of thermoplastic composites include higher damage tolerance, corrosion resistance, higher impact resistance and enhanced fatigue life. Due to their recyclable and re-formable natures, thermoplastic composites are selected for environmentally benign applications. ${ }^{1-4}$

The welding process is one of the preferred methods to realize the assembly structure of thermoplastic composites. This method eliminates disadvantages such as stress concentration and the galvanic corrosion of mechanical fastenings. Also, the thermoplastic matrix has its own specific welding parameters with much the same reinforcements. In the welding zone the dispersion of the reinforcement and orientation could be affected by the welding pressure, heating, heating time and some similar properties, which results in the corruption on unity for the reinforced thermoplastic. ${ }^{5-7}$

Some researchers have worked on different welding methods for thermoplastic composites. At present, there is still not enough literature available related to the process parameters and their influence on the joint's strength.

C. B. Bucknall et al. ${ }^{8}$ reported that the weld strengths of glass-fiber-reinforced polypropylene were strongly affected by the hot-plate temperature, heating time, and melt flow during welding. K. V. Stokes ${ }^{5}$ has studied the fatigue life of vibration-welded unreinforced polycarbonate $(\mathrm{PC})$, polyetherimide (PEI), modified polyphenylene oxide resin (M-PPO) and poly (butylenes terephthalate) (PBT), under tension-tension loading at $R=0.1$. The first three polymers are amorphous and PBT is semi-crystalline. K. V. Stokes ${ }^{5}$ found that the ratio of the endurance limit stress to the tensile strength was 0.29 for PC, 0.34 for PEI, 0.22 for M-PPO and 0.31 
Table 1: Thermoplastic materials and glass-fiber properties used in the experiments

Tabela 1: Lastnosti termoplastičnega materiala in steklenih vlaken, uporabljenih pri preizkusih

\begin{tabular}{|c|c|c|c|c|c|}
\hline Material & Producer & Density & MFI (g/10min) & Melting temp. & $\begin{array}{c}\text { Vicat soft. temp. } \\
\left({ }^{\circ} \mathrm{C}\right)\end{array}$ \\
\hline $\begin{array}{c}\text { Polipropilen } \\
\text { (S.R.L) }\end{array}$ & ROM Petrol & 0.90 & 20 & 165 & 132 \\
\hline PP-g-MA & Sigma Aldrich & 0.95 & 115 & 152 & 147 \\
\hline Material & Producer & Dimensions & $\begin{array}{c}\text { Density } \\
\left(\mathrm{gr} / \mathrm{cm}^{3}\right)\end{array}$ & $\begin{array}{c}\text { Tensile strength } \\
(\mathrm{MPa})\end{array}$ & $\begin{array}{c}\text { Melting temp. } \\
\left({ }^{\circ} \mathrm{C}\right)\end{array}$ \\
\hline Glass Fiber & Cam Elyaf A.Ş. & $\begin{array}{c}\text { D: } 10.5 \mu \mathrm{m} \\
\text { L: } 4.5 \mathrm{~mm}\end{array}$ & 2.54 & 3450 & $\begin{array}{c}\text { Annotations } \\
1722\end{array}$ \\
\hline
\end{tabular}

for PBT. T. T. Lin et al. ${ }^{9}$ investigated the effect of welding parameters on the non-contact hot-plate butt welding of polypropylene. For a given hot-plate temperature, an optimum heating time and forging pressure were found. M. Watson et al. ${ }^{10}$ investigated the parameters of heated tool welding. The heated tool temperature has been found to be a less critical parameter than either the heating pressure or time.

These studies mostly concentrate on the parameters of the welding process, such as the heating time, the tool temperature and the pressure. But they lack the comparison of composites that had a chemical treatment of a matrix material like maleic anhydride (MA). There is a need to better understand the influence of various processing parameters and the coupling agent (MAPP) on the joint properties of hot tool welded thermoplastic composites. In accordance with previous studies published in the literature about the fatigue life of SGFR thermoplastics, the fatigue scattering is small, especially in comparison with the fatigue of metallic materials.

The final goal of this study is to gain a better understanding of the effects of using a coupling agent (MAPP) and the heating time parameter on the welding properties of hot tool welded composites. For constant temperatures and reinforced MAPP with a different ratio, thermoplastic composite component's butt welded joint strength, failure strain, modulus of elasticity and fatigue properties that depend on the heating time and cyclic number were compared by using the tensile and the fatigue-tests method. Non-welded material data are also included as a reference. The results are analyzed using curves for the stress versus the number of cycles to failure $(\mathrm{S}-\mathrm{N})$ for the fatigue test.

\section{MATERIALS AND EXPERIMENTAL PROCEDURES}

\subsection{Materials}

The resins used in this study were commercially available, virgin-grade polypropylene (PP) S.R.L., polypropylene-grafted maleic anhydride (PP-g-MA (Sigma Aldrich), MA content $=1 \%$ of mass fraction) chopped into strands of glass fiber PA2-4.5 (Cam Elyaf Inc.). Table 1 lists the properties of the resins as provided by the resin producer. Glass-fiber-reinforced PP granules were prepared with a lab-type single-screw extruder (L/D: 28). And then the granules were shaped as $200 \times 200 \mathrm{~mm}^{2}$ plates using a hot press. The samples were obtained from the plates with a cutting press. ISO 527 tensile-test procedures were used in this investigation. Three identical samples of each composition (Table 2) were measured and the average values were reported.

Table 2: Thermoplastic composites used in the experiments Tabela 2: Termoplastični kompoziti, uporabljeni za preizkuse

\begin{tabular}{|c|c|c|c|}
\hline Material type & PP $(w / \%)$ & MA-g-PP $(w / \%)$ & GF $(w / \%)$ \\
\hline PPv (virgin) & 100 & - & - \\
\hline PP20GF & 80 & 0 & 20 \\
\hline MA2.5PPGF & 77.5 & 2.5 & 20 \\
\hline MA5PPGF & 75 & 5 & 20 \\
\hline
\end{tabular}

\subsection{Welding method}

In the non-contact hot-tool welding process, the parts being welded are placed near the hot tool separated from it by a distance referred to as the non-contact gap. The hot tool is removed during the change-over phase. Pressure is applied to hold the parts in close contact during weld cooling and solidification. The heat is transferred by thermal radiation and convection. The process is otherwise identical to hot-tool welding: the hot plate is removed in the changeover phase, and pressure is applied to achieve close contact as the weld cools and solidifies. ${ }^{8}$ The non-contact hot-tool or hot-plate welding has processing parameters that influence the weld strength, which include the size of the non-contact gap, the platen temperature, heating time, change-over time, weld pressure and duration. A butt-type joint has a lower weld line strength at a low welding pressure. ${ }^{11}$ The welding and tensile test steps are shown as an example in Figure $\mathbf{1 .}$

During the welding process, the heat transfer raises the temperature of the part and the resulting thermal expansion causes a small rightward (away from the hot-tool surface) motion in the part and fixture. When the surface temperature reaches the melting point of the plastic the part surface begins to melt. The externally applied pressure causes the molten material to flow laterally outwards, thereby inducing a leftward motion of the part. ${ }^{8}$

In non-contact heated tool welding, the contamination of the weld surfaces is minimized, the heating is 


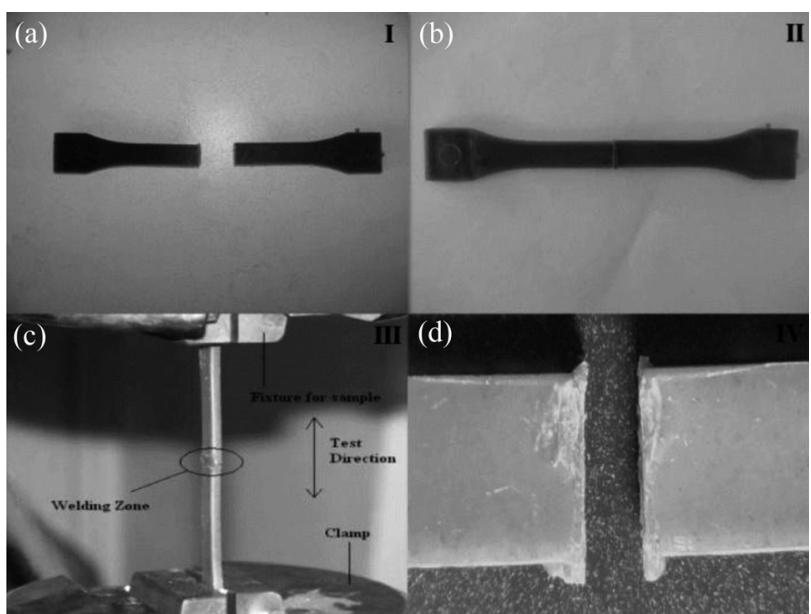

Figure 1: Welding and tensile test procedure of a sample: a) divide injection-molded sample into two parts, b) joint samples by welding, c) tensile testing of welded part, d) failure on welded parts after tensile test

Slika 1: Postopek varjenja in preizkušanja vzorca: a) dva dela razdeljenega tlačno litega vzorca, b) zvarjen vzorec, c) natezni preizkus zvara, d) porušen zvar po nateznem preizkusu

uniform, and a small weld bead is produced, providing good, consistent weld strengths. ${ }^{11}$ An important aspect was the heat-soak time, which was influential in obtaining high joint strengths. Ideally, the stops should be as close to the joint interface as possible, consistent with bringing the joint interface into close contact with the heating element.

The experimental activity was carried out with the aim of evaluating the static and fatigue behavior under tension loadings of single lap welded joints in composite materials and to investigate the mechanics of damage evolution.

In this study the mechanical performance of the weld was obtained using rectangles of injection-molded samples that were welded together. The dimensions of the samples have enough tolerance for the welding process. Two parts were joined under heat that was generated by the stainless-steel hot-tool plate with dimensions of $40 \mathrm{~mm} \times 2 \mathrm{~mm} \times 100 \mathrm{~mm}$. The weld line temperature was manually controlled with an InfraRed thermometer (CEM DT-8835, K-Type). The sets of these test samples and test parameters are given in Table 3. The weld area is equal to $40 \mathrm{~mm}^{2}$. The welding pressure was held at constant values of $0.5 \mathrm{MPa}$ and $4 \mathrm{MPa}$. For each type of thermoplastic composite a welding temperature of $260{ }^{\circ} \mathrm{C}$ was applied. ${ }^{12}$ The non-contact gap was $1 \mathrm{~mm}$. A constant heating displacement and weld displacement were maintained during the experiments. The heating temperature was chosen as an optimum value that is common to welding on all types of thermoplastic composite welding. The range for the heating time was $40 \mathrm{~s}$ to $70 \mathrm{~s}$. The weld was always situated in the middle of the specimen, perpendicular to the load line.

\subsection{Tensile test}

In this study the tensile tests were performed using an Instron Universal Testing Machine Model 8501, equipped with a 500-kg load cell, a strain-gauge extensometer (Instron, model $2620, \mathrm{UK}$ ) after conditioning at $23 \pm 2{ }^{\circ} \mathrm{C}$ according to the ISO 527 standard. The cross-head speed used for the type IA tensile specimens was $5 \mathrm{~mm} / \mathrm{min}$. All the samples were $150 \mathrm{~mm}$ in length with a bonded butt (flat) type. The tests were performed in triplicate and the results reported are the arithmetic average of the parallel samples.

The dog-bone-shaped sample is routed down to a standard ISO 527 tensile test specimen with a butt joint at its center. The tensile sample, which has a transverse butt weld at mid-length, is then subjected to a constantdisplacement-rate tensile test in which the strain across the weld is monitored with an extensometer. In this way the average failure strain across the weld over a $25 \mathrm{~mm}$ gauge length can be monitored.

\subsection{Fatigue test}

Load-controlled fatigue tests were performed in the tension-tension mode at ambient temperature (approximately $23{ }^{\circ} \mathrm{C}$ ). The specimens were tested under a sinusoidal waveform at various loads between $35 \%$ and $80 \%$ of the static damage initiation load according to ASTM D 3479 (tension-tension fatigue behavior). The tests were conducted under a load ratio $R=0.1$ and a frequency $f=5 \mathrm{~Hz}$. No significant heating was noticed during the fatigue testing. When specimen failure could

Table 3: Some parameters of the experimental procedure for the study and sample codes (welding temp. $260{ }^{\circ} \mathrm{C}$ )

Tabela 3: Nekateri parametri preizkusov in oznake vzorcev (temperatura varjenja $260{ }^{\circ} \mathrm{C}$ )

\begin{tabular}{|c|c|c|c|c|c|}
\hline Materials & $\begin{array}{l}\text { Heating time } \\
\text { (s) }\end{array}$ & $\begin{array}{c}\text { Welding pressure (MPa) } \\
\text { Part I/Part II }\end{array}$ & Materials & $\begin{array}{l}\text { Heating time } \\
\text { (s) }\end{array}$ & $\begin{array}{c}\text { Welding pressure (MPa) } \\
\text { Part I/Part II }\end{array}$ \\
\hline \multirow{4}{*}{$\mathrm{PPV}$} & 40 & $0.5 / 4 \mathrm{MPa}$ & \multirow{4}{*}{ MA2.5PPGF } & 40 & $0.5 / 4 \mathrm{MPa}$ \\
\hline & 50 & $0.5 / 4 \mathrm{MPa}$ & & 50 & $0.5 / 4 \mathrm{MPa}$ \\
\hline & 60 & $0.5 / 4 \mathrm{MPa}$ & & 60 & $0.5 / 4 \mathrm{MPa}$ \\
\hline & 70 & $0.5 / 4 \mathrm{MPa}$ & & 70 & $0.5 / 4 \mathrm{MPa}$ \\
\hline \multirow{4}{*}{ PP20GF } & 40 & $0.5 / 4 \mathrm{MPa}$ & \multirow{4}{*}{ MA5PPGF } & 40 & $0.5 / 4 \mathrm{MPa}$ \\
\hline & 50 & $0.5 / 4 \mathrm{MPa}$ & & 50 & $0.5 / 4 \mathrm{MPa}$ \\
\hline & 60 & $0.5 / 4 \mathrm{MPa}$ & & 60 & $0.5 / 4 \mathrm{MPa}$ \\
\hline & 70 & $0.5 / 4 \mathrm{MPa}$ & & 70 & $0.5 / 4 \mathrm{MPa}$ \\
\hline
\end{tabular}




\section{S. E. ERDOGAN, U. HUNER: THE EFFECT OF THE WELDING PARAMETERS AND THE COUPLING AGENT ...}

not be obtained within 1 million cycles, the test was terminated and an indefinite fatigue life was reported. Between 10 and 15 specimens were tested for each material. The fracture surfaces of the broken specimens were observed visually and using scanning electron microscopy (SEM). The samples were first sputter coated with a fine layer of gold under vacuum for $60 \mathrm{~s}$. An accelerating voltage of $20 \mathrm{kV}$ was used to collect the SEM images.

\section{RESULTS AND DISCUSSION}

\subsection{Tensile test results}

The results of the static tests are presented in terms of both nominal tensile stress on the adherents and shear stress on the adhesive. The aim of this is to provide information on the load-carrying capability of the joints and the adhesive properties. It is a well-known fact that the welding quality is influenced by many processing factors, some of these being the welding time and the welding pressure. It is therefore important to explore the best combination of these factors to obtain the best welding result. Considering the used filler content, it was verified that for all the tested composites the tensile strength increases by the welding time and considering the shape of filler content, the type of fiber for the filler content achieved a relatively high strength compared to the other reinforced PP composites. This happens because the fiber adhesion to the matrix is enough, when compared with the others, to increase the matrix tension's transfer efficiency through the interface and that is essential to get an improvement of the mechanical properties in the composite.

For each time period (40 s, 50 s, 60 s, 70 s) three parallel samples were used and the results reported are the arithmetic average of the parallel samples. The joint

Table 4: Comparing the results of joint strength and failure strain for the welded samples Tabela 4: Primerjava rezultatov trdnosti spojev in raztezek pri porušitvi zvarjenih vzorcev

\begin{tabular}{|c|c|c|c|c|c|c|c|}
\hline Materials & $\begin{array}{l}\text { Heating } \\
\text { time }(s)\end{array}$ & $\begin{array}{l}\text { Joint strength } \\
\text { (MPa) I }\end{array}$ & $S_{\mathrm{d}}^{* * *}$ & $\begin{array}{c}\sigma_{\mathrm{w} /} \sigma_{\mathrm{b}} * \\
\mathrm{I}\end{array}$ & $\begin{array}{l}\text { Joint strength } \\
\text { (MPa) II }\end{array}$ & $S_{\mathrm{d}}$ & $\begin{array}{c}\sigma_{\mathrm{w}} / \sigma_{\mathrm{b}} \\
\text { II }\end{array}$ \\
\hline \multirow{4}{*}{$\begin{array}{c}\text { PPv } \\
\text { (Bulk strength } 32 \mathrm{MPa} \text { ) }\end{array}$} & 40 & 17.84 & 7.55 & 0.55 & 14.53 & 5.86 & 0.45 \\
\hline & 50 & 20.16 & 9.77 & 0.63 & 17.66 & 6.53 & 0.55 \\
\hline & 60 & 23.42 & 8.02 & 5.73 & 20.45 & 7.94 & 0.63 \\
\hline & 70 & 26.11 & 8.51 & 5.81 & 23.71 & 12.84 & 0.74 \\
\hline \multirow{4}{*}{$\begin{array}{c}\text { PP20GF } \\
\text { (Bulk strength } 41 \mathrm{MPa})\end{array}$} & 40 & 24.15 & 10.87 & 4.58 & 20.31 & 9.12 & 0.49 \\
\hline & 50 & 26.34 & 11.14 & 7.55 & 22.59 & 6.35 & 0.55 \\
\hline & 60 & 33.18 & 15.97 & 9.11 & 29.16 & 8.74 & 0.71 \\
\hline & 70 & 37.77 & 16.23 & 8.92 & 33.94 & 10.81 & 0.82 \\
\hline \multirow{4}{*}{$\begin{array}{c}\text { MA2.5PPGF } \\
\text { (Bulk strength } 44 \mathrm{MPa})\end{array}$} & 40 & 30.24 & 10.88 & 1.68 & 27.76 & 8.54 & 0.63 \\
\hline & 50 & 35.61 & 12.01 & 6.80 & 32.59 & 8.62 & 0.74 \\
\hline & 60 & 38.22 & 14.11 & 5.77 & 38.93 & 10.88 & 0.88 \\
\hline & 70 & 40.78 & 18.14 & 6.92 & 40.56 & 11.99 & 0.92 \\
\hline \multirow{4}{*}{$\begin{array}{c}\text { MA5PPGF } \\
\text { (Bulk strength } 48 \mathrm{MPa})\end{array}$} & 40 & 36.45 & 10.78 & 1.75 & 32.98 & 9.21 & 0.68 \\
\hline & 50 & 39.27 & 12.28 & 4.81 & 35.26 & 10.54 & 0.73 \\
\hline & 60 & 41.48 & 17.33 & 3.86 & 36.48 & 13.33 & 0.76 \\
\hline & 70 & 46.25 & 19.71 & 6.96 & 40.58 & 10.27 & 0.92 \\
\hline Materials & $\begin{array}{l}\text { Heating } \\
\text { time }(\mathrm{s})\end{array}$ & $\begin{array}{l}\text { Failure strain } \\
(\%) \mathrm{I}\end{array}$ & $S_{\mathrm{d}}^{* * *}$ & $\begin{array}{c}\varepsilon_{\mathrm{W} /} \varepsilon_{\mathrm{b}}{ }^{* *} \\
\mathrm{I}\end{array}$ & $\begin{array}{l}\text { Failure strain } \\
(\%) \text { II }\end{array}$ & $S_{\mathrm{d}}$ & $\begin{array}{c}\varepsilon_{\mathrm{W} /} \varepsilon_{\mathrm{b}} \\
\text { II }\end{array}$ \\
\hline \multirow{4}{*}{$\begin{array}{c}\text { PPv } \\
\text { (Bulk material strain } \\
\varepsilon_{0}=4.56 \% \text { ) }\end{array}$} & 40 & 3.51 & 1.3 & 0.77 & 3.14 & 1.72 & 0.69 \\
\hline & 50 & 3.76 & 0.7 & 0.82 & 3.05 & 2.02 & 0.67 \\
\hline & 60 & 4.11 & 2.2 & 0.90 & 2.87 & 0.97 & 0.63 \\
\hline & 70 & 4.18 & 2.4 & 0.92 & 2.56 & 1.12 & 0.56 \\
\hline \multirow{4}{*}{$\begin{array}{c}\text { PP20GF } \\
\text { (Bulk material strain } \\
\left.\varepsilon_{0}=0.58 \%\right)\end{array}$} & 40 & 0.51 & 0.16 & 0.88 & 0.40 & 0.14 & 0.69 \\
\hline & 50 & 0.45 & 0.04 & 0.78 & 0.34 & 0.12 & 0.59 \\
\hline & 60 & 0.41 & 0.13 & 0.71 & 0.29 & 0.09 & 0.50 \\
\hline & 70 & 0.36 & 0.08 & 0.62 & 0.26 & 0.11 & 0.45 \\
\hline \multirow{4}{*}{$\begin{array}{c}\text { MA2.5PPGF } \\
\text { (Bulk material strain } \\
\varepsilon_{0}=0.35 \% \text { ) }\end{array}$} & 40 & 0.22 & 0.04 & 0.63 & 0.16 & 0.06 & 0.46 \\
\hline & 50 & 0.17 & 0.04 & 0.49 & 0.11 & 0.08 & 0.31 \\
\hline & 60 & 0.11 & 0.03 & 0.31 & 0.06 & 0.02 & 0.17 \\
\hline & 70 & 0.08 & 0.01 & 0.23 & 0.04 & 0.02 & 0.11 \\
\hline \multirow{4}{*}{$\begin{array}{c}\text { MA5PPGF } \\
\text { (Bulk material strain } \\
\varepsilon_{0}=0.24 \% \text { ) }\end{array}$} & 40 & 0.17 & 0.04 & 0.71 & 0.14 & 0.07 & 0.58 \\
\hline & 50 & 0.15 & 0.06 & 0.63 & 0.11 & 0.03 & 0.46 \\
\hline & 60 & 0.07 & 0.06 & 0.29 & 0.04 & 0.01 & 0.17 \\
\hline & 70 & 0.05 & 0.02 & 0.21 & 0.02 & 0.01 & 0.08 \\
\hline
\end{tabular}

$* \sigma_{\mathrm{w} /} \sigma_{\mathrm{b}}$ (Relative strength), ${ }^{*} * \varepsilon_{\mathrm{w} /} \varepsilon_{\mathrm{b}}$ (Relative strain), $* * * S_{\mathrm{d}}$ (Standard deviation) 
strength of the welded samples and the bulk strength of unwelded samples are compared in Table 4. All of the welded assemblies of virgin and reinforced polypropylene failed at the weld lines. All the glass-fiber-reinforced parts were found to fracture at the weld interfaces. The results suggested that the hot-plate-welded MA5PPGF composite parts exhibited the highest joint strength on $0.5 \mathrm{MPa}$ weld pressure, followed by the MA2.5PPGF and PP20GF composites. The welded virgin polypropylene showed the lowest joint strengths.

It is clear that a weld does not represent just a discontinuity in the material, but is the source of an extended mechanical disturbance, which strongly influences the local material's behavior, even at a distance outside the weld. ${ }^{13}$ It can be noticed that for the higher MA-g-PP/GF content the local strain (Table 4) in the accompanying zones is lower, which corresponds to the lower compliance of the reinforced material. Also, in this case the lower pressure results in a local strain super elevation at the weld. The range of fiber orientation inside the weld is only very low, so that the material showing a higher degree of deformation and damage at the same weld
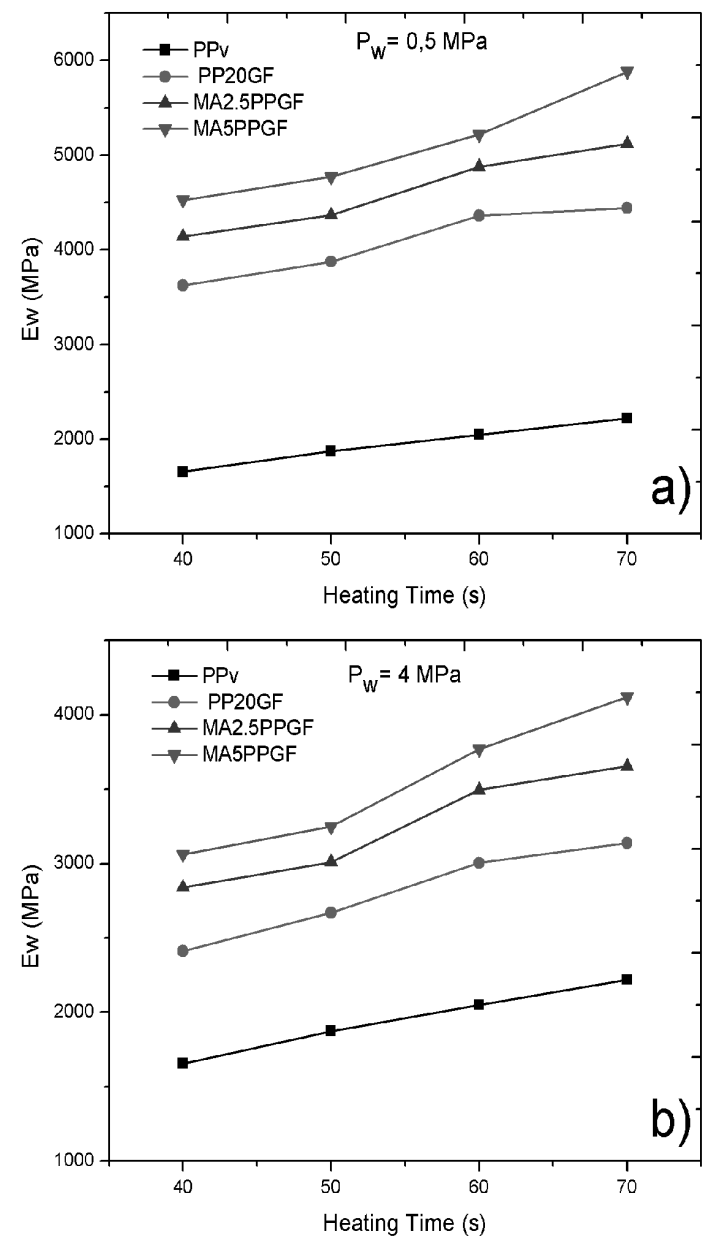

Figure 2: a) Modulus of welded samples under 0.5 MPa weld pressure, b) modulus of welded samples under $4 \mathrm{MPa}$ weld pressure Slika 2: a) Modul zvarjenih spojev pri 0,5 MPa tlaku zvara, b) modul zvarjenih vzorcev pri $4 \mathrm{MPa}$ tlaku zvara pressure governs the mechanical behavior for the whole weld range.

As the amount of MAPP increases the joint strength increases to a $0.5-\mathrm{MPa}$ weld pressure as reported in Table 4, but the joint strength of the samples decreases with less than $4 \mathrm{MPa}$ weld pressure. Similar results have been reported by J. S. Liu, H. F. Cheng ${ }^{13}$ Under the influence of the welding pressure, the plasticized material in the weld zone flows. With increasing penetration, fibers push out of the surface. This fiber bridging causes a high weld strength. But increasing the welding pressure causes a high degree of orientation transverse to flow (injection) to the original fiber alignment. This in turn leads to a decrease in the joint strength.

The modulus $(E)$ of the material is also reported in Figure 2. With respect to $\mathrm{PPv}$, they have higher moduli and strengths, but they break at a lower strain. The differences in the E of the PP-based composites cannot be ascribed to their different composition because in that case, E should monotonically decrease with the welding pressure.

Increasing the hot-plate heating time increases the temperatures of the materials. The temperature provides the necessary movement of the melt flow, and time is needed for the diffusion to occur. A higher material temperature therefore aids increasing the weld strengths. Homogenous filler orientation such as fiber on the welding zone and matrix material dominates the stress behavior. Fiber reinforcements lead to an increase of the melting point of the matrix. The random orientation of glass fiber on the welding zone affects the welding strength depending on the heating time. Increasing the heating time thereby the melting length leads to increasing fiber orientation horizontal to the direction of the load. With the increasing melting length fibers move to the welding zone while the melt flows out. The results that depend on heating time have provided a comparison for a variety of filler-reinforced PP composites. M. Gehde et al. ${ }^{14}$ have investigated the effect of melting length and joining length for different heating times $(0 \mathrm{~s}, 60 \mathrm{~s}$ and $120 \mathrm{~s}$ ) on the material reinforced PP with a random glass mat (PP-GM). PP-GM attains the highest strength at a low joining length. Varying the melting length does not affect the maximum strength of $28 \mathrm{MPa}$. In this study, 46.25 $\mathrm{MPa}$, the highest strength value of the welding, was obtained for a low welding pressure, which means a low joining length. This strength was reached at a time of $60 \mathrm{~s}$. The higher strength values from the literature can be said to be associated with the use of MA. MA-gPP usage, increasing the fiber adhesion, also on the welding interface, has fulfilled its function of improving the strength in the basic structure. The MA-g-PP (5\%), approximately $20 \%$ difference between using and not using the welding strength of the composite were determined at low/high weld pressures.

The SEM observation at the fracture surface suggests that the welded MA5PPGF materials have fewer fibers 


\section{S. E. ERDOGAN, U. HUNER: THE EFFECT OF THE WELDING PARAMETERS AND THE COUPLING AGENT ...}

that are oriented horizontal to the direction of load 0.5 $\mathrm{MPa}$, when compared to that of the welded MA5PPGF composites (Figure 3) on the pressure load of $4 \mathrm{MPa}$. The joint strengths of the welded MA5PPGF at a 4-MPa weld pressure may thus be inferior to that of the MA5PPGF composites welded a 0.5-MPa weld pressure. Many transverse fibers were widely detached and sometimes fibers in longitudinal direction of the specimen were broken. Additionally, the squeezed-out plastic melt generates a flash, resulting in a sharp transition in the cross-section of the product. ${ }^{8}$ For a welding pressure of 4 $\mathrm{MPa}$, the SEM micrographs show that the fibers that bridge the weld zone are shorter than those at a pressure of $0.5 \mathrm{MPa}$. Therefore, the region with fibers protruding from the weld is smaller, and the fiber orientation in the direction of the flash increases.

\subsection{Fatigue test results}

There are many factors that govern the fatigue behavior of discontinuous fiber-reinforced polymer-matrix composites. Some of these include the processing conditions, the fiber length and the orientation with respect to the loading axis, the properties of the matrix, interfacial properties, and testing conditions. The fibers tend to orient along the flow direction, which leads to superior mechanical properties along the flow direction. As the degree of fiber disorientation with respect to the

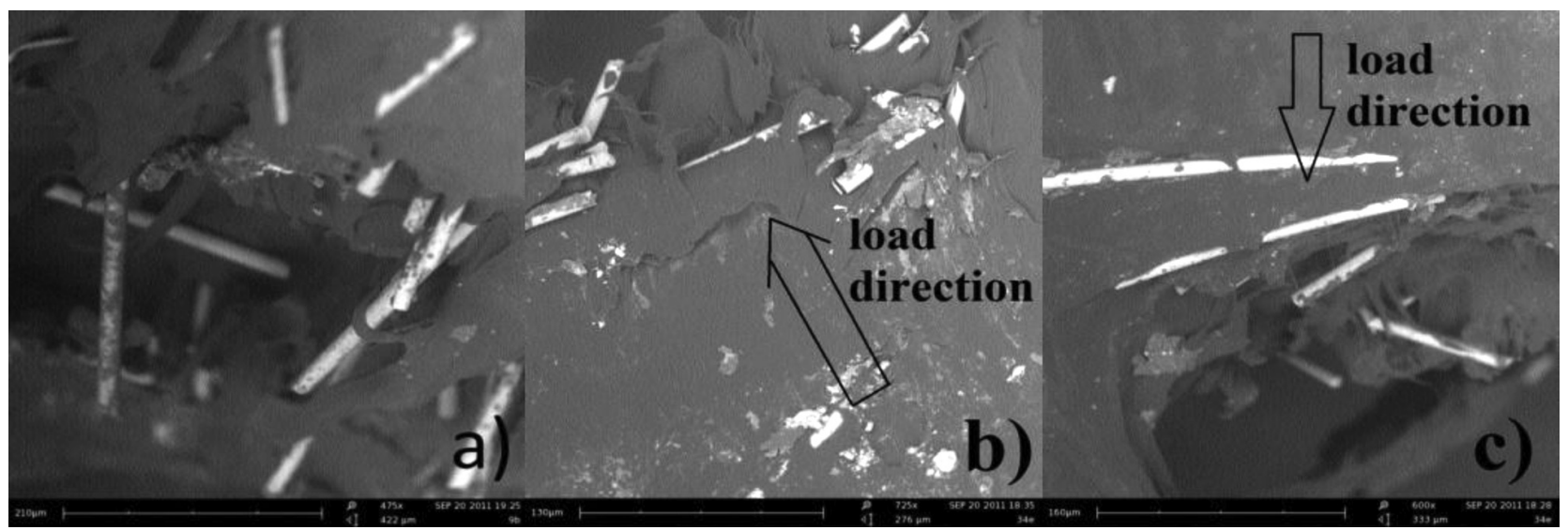

Figure 3: a) Increasing fiber orientations in the direction of the flash, b) MA5PPGF composite interface with fiber orientation at 4-MPa welding pressure, c) MA5PPGF composite interface, fibers oriented horizontal to the direction of load $0.5 \mathrm{MPa}$

Slika 3: a) Naraščanje usmerjenosti vlaken v smeri svetlobe, b) MA5PPGF stika kompozita z usmerjenostjo vlaken pri tlaku varjenja $4 \mathrm{MPa}$, c) MA5PPGF stik kompozita, vlakna so usmerjena horizontalno v smeri obremenitve z 0,5 MPa
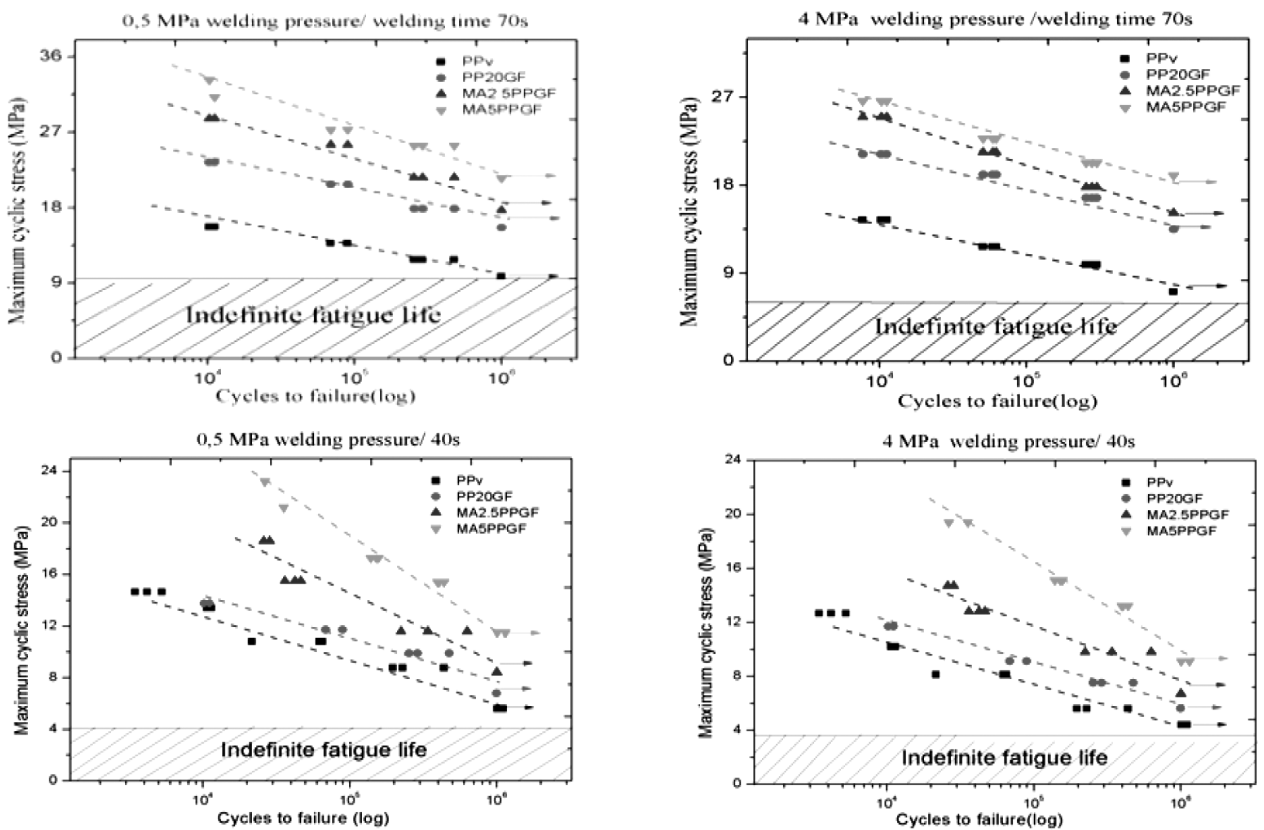

Figure 4: $S$ - $N$ curves at $R=0.1$ for glass-fiber-reinforced PP with weld pressure of $0.5 \mathrm{MPa}(\mathrm{LP}), 4.0 \mathrm{MPa}(\mathrm{HP})$ and PPv (unreinforced), (arrows indicate unbroken specimens)

Slika 4: $S$ - $N$ krivulje pri $R=0,1$ za PP ojačan s steklenimi vlakni, pri tlaku varjenja 0,5 MPa (LP), 4 MPA (HP) in PP (neojačan), (puščice kažejo na neporušene vzorce) 


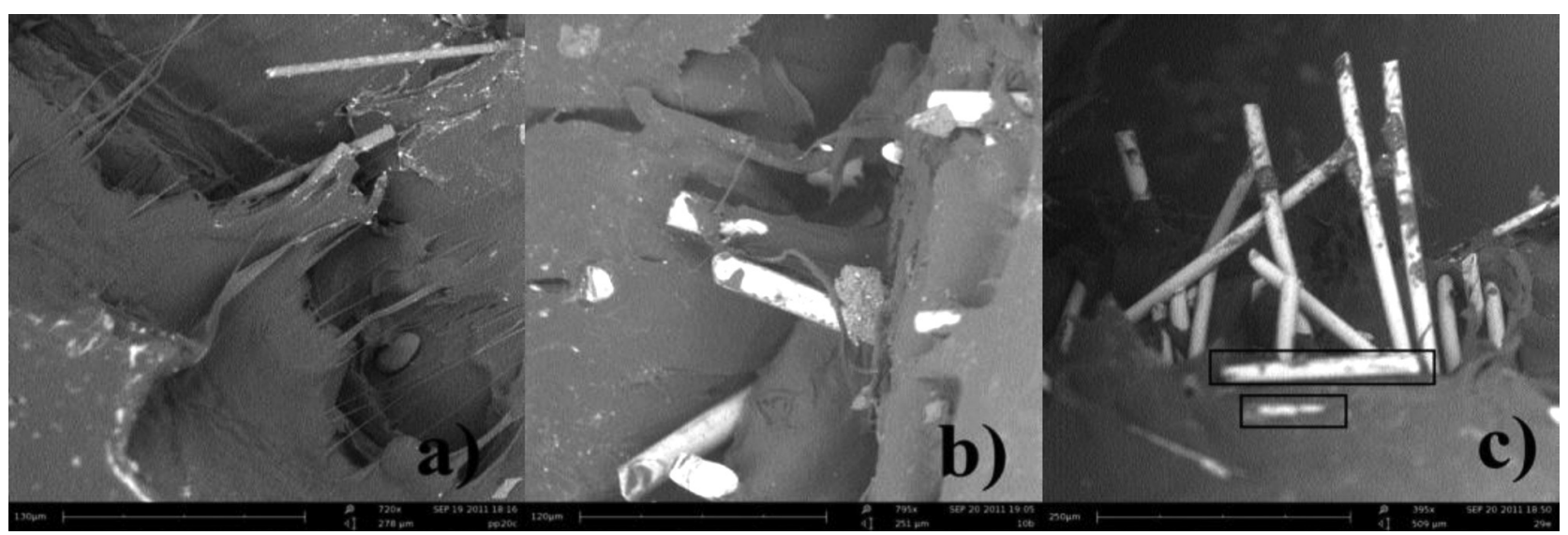

Figure 5: a) The matrix adhering to the fiber (at high pressure), b) matrix sticking to the fiber can be clearly seen and the orientation of the fibers perpendicular to the weld line. The sample exhibited a similar fracture surface as shown by the tensile specimen with the matrix sticking to the surface, c) fibers oriented to the center of the weld interface (rectangle area).

Slika 5: a) Matrica, ki se je prijela na vlakno (pri visokem tlaku), b) osnova, ki se je prijela na vlakno se dobro vidi in orientacija vlakna je pravokotna na linijo zvara. Vzorec kaže enako površino preloma kot pri nateznem preizkušancu, kjer se je osnova prilepila na površino, c) vlakna v sredini zvara (pravokotna področja).

loading axis increases, the strength of the composite is increasingly dominated by the matrix and interfacial properties. ${ }^{15-20}$

All the fatigue data were preliminarily analyzed using the classic stress-life approach and drawing the fatigue curves based on the nominal stress and the number of cycles to failure, identified as the complete separation of the joints. Figure 4 presents the fatigue performance for all four materials as a plot of the maximum cyclic stress versus the number of cycles to failure, on a semi-log scale ( $\mathrm{S}-\mathrm{N}$ plot). Figure $\mathbf{4}$ also reports the S-N curves of glass-fiber-filled polypropylene samples that were welded under a $0.5-\mathrm{MPa}$ weld pressure and $4 \mathrm{MPa}$ weld pressure. The vertical axis represents the maximum cyclic stress and the horizontal axis is the number of fatigue cycles to failure in this figure.

The stress-life approach allows the influence of the design parameters under investigation to be clearly identified. ${ }^{21-23}$ In fact, an increase in the fatigue strength of the joints and therefore in their load capability can be observed when the welding pressure decreases for the joint process. Even the influence of the weld pressure itself can be easily identified in Figure 4. In terms of absolute stress, as could be expected from the static tests, MA5PPGF specimens exhibited better performance. Analyzing the fatigue diagrams, the low-pressure welding process led to a higher fatigue strength. At the welding pressure of $0.5 \mathrm{MPa}$, the highest strength values were achieved with the MA5PPGF material. Based on this result, in the welding zone, the fiber orientation is parallel to the applied force direction. The samples were welded under a pressure of $4 \mathrm{MPa}$, and the test results showed that the fatigue strength decreased. While MA5PPGF material strength again showed the highest fatigue strength of $26.88 \mathrm{MPa}$ at about 9500 cycle, this load level represents $80 \%$ of the static damage initiation load, which is similar to the findings of previous studies on the welding of thermoplastic composites. ${ }^{15,16} \mathrm{~K}$. J. Tsang et al. ${ }^{16}$ also reported that the fatigue life of specimens welded at low pressure was $50 \%$ greater than that of the specimens welded at high pressure, this study's results showed an $18 \%$ fatigue life increase at low pressure. The low-weld-pressure condition shows more fibers oriented perpendicular to the weld plane, which may have increased the weld strength and resulted in a longer fatigue life. When the effects on the strength of the welding reinforcement by MAPP are analyzed, using MAPP material at a low rate $(2.5 \%)$ provided protection of the weld strength at a low weld pressure. The MAPP2,5PP material showed similar results (Figure 5) under a fatigue load, neither at a low welding pressure nor at a high welding pressure This tendency is also seen in the tensile-strength value (Table 4).

Figures $5 \mathbf{a}$ to $\mathbf{5} \mathbf{c}$ show the fatigue fracture surfaces of reinforced PP specimens welded at low and high pressures. The low-weld-pressure condition shows more fibers oriented perpendicular to the weld plane (Figure $\mathbf{5 b}$ ), which may have increased the weld strength and resulted in a longer fatigue life. This is consistent with the fracture surface observed in previous studies. ${ }^{8}$ For reinforced material, the fatigue crack propagation process is more local and on a smaller scale compared with that of the unreinforced material due to the presence of glass fibers.

\section{CONCLUSIONS}

This study has examined the effect of different processing parameters on the joint strength of hot-plate welded thermoplastic composites, including the heating time, weld pressure and using MA-treated polypropylene. Four materials were used in the study: virgin polypropylene, $20 \%$ glass fiber, $2.5 \%$ MAPP (and $20 \%$ 


\section{S. E. ERDOGAN, U. HUNER: THE EFFECT OF THE WELDING PARAMETERS AND THE COUPLING AGENT ...}

glass fiber), $5 \%$ MAPP (and $20 \%$ glass fiber) reinforced polypropylene composites.

With the increased welding time, the tensile strength increased and this was found to be reversed by correlating the welding pressure.

At a low welding pressure the MAPP material provides increased tensile strength of the glass-fiber-reinforced PP at about a rate of $50 \%$. Under a high welding pressure the MAPP increases the tensile strength, but it is seen that when using $2.5 \%$ of that $5 \%$ of any contribution when used.

The fatigue behavior gets worse and the fatigue limit of the tested material decreases when the weld pressure increases. As well as this, the welding time shows similar trends to the weld pressure. While contributing positively to the use of MAPP fatigue strength, the strength drop caused by the pressure increase was partially blocked.

\section{REFERENCES}

${ }^{1}$ M. Hou, Y. Ye, Y. W. Mai, An Experimental Study of Resistance Welding of Carbon Fiber Fabric Reinforced Polyetherimide (CF Fabric/PEI) Composite Material, Applied Composite Materials, 6 (1999) 1, 35-49, doi:10.1023/A:1008879402267

${ }^{2}$ M. Hou, M. Yang, B. Andrew, Y. W. Mai, L. Ye, Resistance Welding Of Carbon Fibre Reinforced Thermoplastic Composite Using Alternative Heating Element, Composite Structures, 47 (1999) 1, 667-672, doi:10.1016/S0263-8223(00)00047-7

${ }^{3}$ J. C. Caraschi, L. A. Leão, Woodflour as Reinforcement of Polypropylene, Materials Research, 5 (2002) 4, 405-409, doi:10.1590/ S1516-14392002000400003

${ }^{4}$ H. G. Karian, Handbook of Polypropylene and Polypropylene Composites, 2nd ed., Marcel Dekker Inc. New York 2003, 653

${ }^{5}$ K. V. Stokes, K. R. Conway, A Phenomenological Study Of The Hot-Tool Welding Of Thermoplastics. Weld Strength Data For Several Blends, Polymer, 42 (2001) 17, 7477-7493, doi:10.1016/ S0032-3861(01)00182-3

${ }^{6}$ M. Xanthos, Functional fillers for plastics, 2nd ed., Wiley-VCH Verlag Gmbh\&Co. KGaA, Weinheim, 2010, 451

${ }^{7}$ William Andrew Publishing, Plastic Design Library, Chapter 1, Available from World Wide Web: http://www.Knovel.com, 1997

${ }^{8}$ C. B. Bucknall, I. C. Drinkwater, G. R. Smith Hot Plate Welding of Plastics: Factors Affecting Weld Strength, Polym. Eng. Sci., 20 (1980) 6, 432-440, doi:10.1002/pen.760200609

${ }^{9}$ T. T. Lin, S. Staicovici, A. Benatar, Non-Contact Hot Plate Welding of Polypropylene, ANTEC (1996), conference proceedings - Society of Plastics Engineers, Orlando, Philadelphia USA 1996
${ }^{10}$ M. Watson, M. Murch, Recent Developments in Hot Plate Welding of Thermoplastics, ANTEC (1989), conference proceedings Society of Plastics Engineers, New York 1989

${ }^{11}$ J. Y. Nieh, L. J. Lee, Morphological characterization of the heataffected zone (HAZ) in hot plate welding, ANTEC (1993), Conference proceedings, Society of Plastics Engineers, New Orleans, 1993

${ }^{12}$ K. Panneerselvam, S. Aravindan, A. Haq Noorul, Study On Resistance Welding Of Glass Fiber Reinforced Thermoplastic Composites, Materials and Design, 41 (2012), 453-459, doi:10.1016/j.matdes. 2012.05.025

${ }^{13}$ J. S. Liu, H. F. Cheng, The Influence of Interface Geometry On The Joint Strength Of Hot Plate Welded Composites, Journal Of Reinforced Plastics and Composites, 29 (2010) 4, 497-509, doi:10.1177/ 0731684408099410

${ }^{14}$ M. Gehde, M. Giese, G. W. Ehrenstein, Welding of thermoplastics reinforced with random glass mat, Polymer Engineering and Science, 37 (1997) 4, 702-715

${ }^{15}$ A. Goel, K. Chawla, U. K. Vaidya, N. Chawla, M. Koopman, Characterization Of Fatigue Behavior Of Long Fiber Reinforced Thermoplastic (LFT) Composites, Materials Characterization, 60 (2009) 6, 537-544, doi:10.1016/j.matchar.2008.12.020

${ }^{16}$ K. Y. Tsang, D. L. DuQuesnay, P. J. Bates, Fatigue Properties of Vibration Welded Nylon 6 And Nylon 66 Reinforced With Glass Fiber, Composites: Part B: Engineering, 39 (2008) 29, 396-404, doi:10.1016/j.compositesb.2007.01.012

${ }^{17}$ K. V. Stokes, Experiments On The Hot-Tool Welding Of Three Dissimilar Thermoplastics, Polymer, 39 (1998) 12, 2469-2477, doi:10.1016/S0032-3861(97)00569-7

${ }^{18}$ P. Mitschang, R. Rudolf, M. Neitzel, Continuous Induction Welding Process, Modelling and Realisation, Journal of Thermoplastic Composite Materials, 15 (2002) 2, 127-153, doi:10.1177/ 0892705702015002451

${ }^{19}$ A. V. Kagan, J. R. Nichols, Benefits of Induction Welding of Reinforced Thermoplastics in High Performance Applications, Journal of Reinforced Plastics and Composites, 24 (2005) 13, 1345-1352, doi:10.1177/0731684405048846

${ }^{20}$ K. V. Stokes, A Phenomenological Study Of The Hot-Tool Welding Of Thermoplastics. Part:1 Polycarbonate, Polymer, 40 (1999) 23, 6235-6263, doi:10.1016/S0032-3861(98)00584-9

${ }^{21}$ M. J. Troughton, Handbook of Plastics Joining, A Practical Guide, 2nd. ed., William Andrew Inc., 2008, 577

${ }^{22}$ C. Bierogel, W. Grellmann, T. Fahnert, R. Lach, Material Parameters For The Evaluation Of PA Welds Using Laser Extensometry, Polymer Testing, 25 (2006) 8, 1024-1037, doi:10.1016/j.polymertesting. 2006.07.001

${ }^{23}$ A. Yousefpour, M. Hojjati, J. P. Immarigeon, Fusion Bonding/Welding of Thermoplastic Composites, Journal of Thermoplastic Composite Materials, 17 (2004) 4, 303-341, doi:10.1177/ 0892705704045187 